両側性顔面神経麻痺の 1 症例

$$
\begin{array}{lll}
\text { 森 } & \text { 良樹·宮脇 } & \text { 浩紀・木村 信次 } \\
\text { 田頭 } & \text { 宣治・多田 } & \text { 渉* }
\end{array}
$$

\title{
A Case of Bilateral Facial Palsy
}

\author{
Yoshiki Mori, Hironori Miyawaki, Shinji Kimura and Nobuharu Tagashira \\ (Hiroshima Red Cross and Atomic-Bomb Survivors Hospital) \\ Wataru Tada \\ (Hiroshima Matsuda Hospital)
}

\begin{abstract}
A review of the literature indicated that peripheral facial palsy was not rare, but that bilateral facial palsy occurred very rarely. We report here a 74 year-old man was treated for bilateral facial palsy. In this case, right facial palsy began 46 days after the onset of a palsy. The left side palsy did not recover in spite of our treatment. Therefore, we decided to perfrom a decompression on the left side. The left facial palsy recovered to about $70 \%$ after the operation.

Therefore, facial nerve palsy showing denervation should be considered for a decompression.
\end{abstract}

Key words : bilateral facial palsy, denervation, decompression

はじめに

片側性顔面神経麻痺は日常診療で時々経験する疾患で 決してまれではない。しかし，両側性となるとその数は 少ないが系統的全身疾患の部分症状として，またべル麻 㽻の場合にもまれに見られることが報告されている1) 33. 今回我々は両側性顔面神経麻㽻の 1 症例を経験したので 文献的考察を含め報告する.

\section{症例}

患者：74歳，男性.

主訴 : 左側顔面麻疩.

現病歷: 平成 9 年 1 月頃より左耳痛を時々自覚するも 放置. 7 月 2 日に左顔面麻痺扣よび後頭部痛を自覚し某 病院耳鼻科を受診、受診時顔面スコア 4 点の麻㽻と左鼓 室に貯留液を認めた。味覚検査では右 $6 \mathrm{~dB}$ 左 $14 \mathrm{~dB}$ と 左の域值上昇を認めた．末梢性顔面神経麻痺に対してプ
レドニン $30 \mathrm{mg}$ 漸減療法, ATP, メコバラミン等の内 服処方された。 また 1 週間後に左耳にチューブ留置を施 行された．20日に及ぶ治療にもかかわらず左顔面神経麻 痺拉よび左の耳漏が持続するため精査加療目的にて当科 を平成 9 年 7 月 24 日に受診した.

既往歴，家族歴に特記すべき事はない。

入院時現症：耳介, 外耳道に皮疹は認めず左鼓膜には チューブが留置されて扣り多量の耳漏を認め, 当科での 菌検の結果はグラム陰性杆菌である acinetobacter が検 出された。右耳は淬出性中耳炎の疑いがあった。 また， 顔面スコアは 0 であった。

入院時検査所見

(1) 神経学的一般検査

顔面神経麻瘦以外の他の脳神経症状を認めなかった。 Guillain-Barre 症候群 (GBS) も疑って神経内科的立場か ら䯣液検查も実施したが，GBS を示唆する所見は認め 
なかった。

(2) 神経耳科学的検査

a . 聴覚的検査

聴力像 (図 1 ) は, 右側は浸出性中耳炎による中等度の 混合性難聴を，左側は高度の感音難聴を認め中耳炎によ る左の内耳障害が疑われた.

当科受診時耳小骨筋反射は貯留液があるため測定不可 能であった。

b. 平衡神経学的検査

病歴上平衡障害はなく, 異常自発眼振も認めなかった.

(dB)

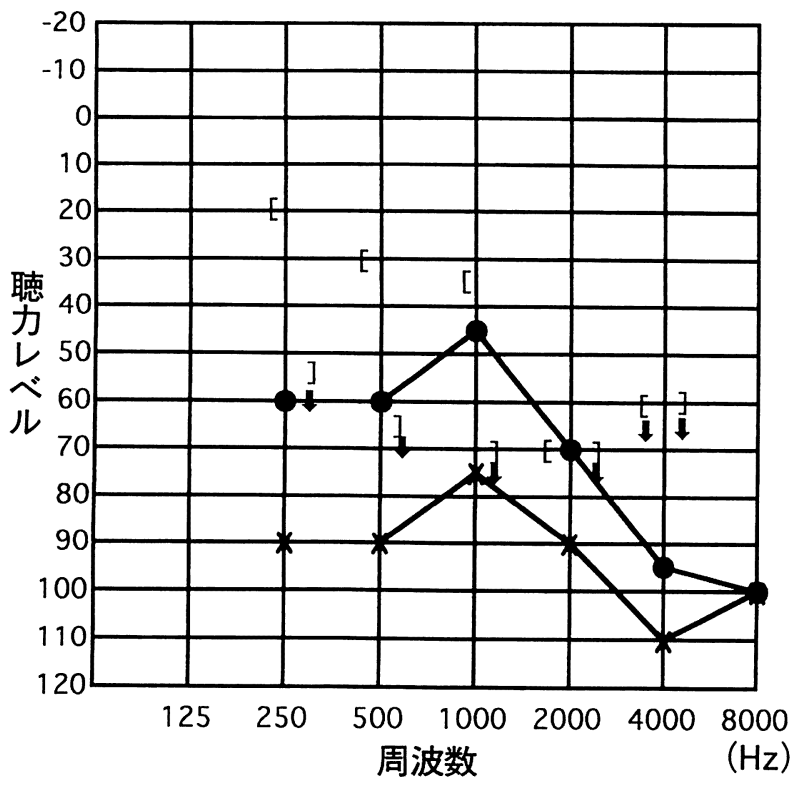

図 1 初診時聴力 c . 顔面神経学的検査

図 2 は左顔面神経麻痺発症後 42 日目の筋電図である. $1.4 \mathrm{mV}$ 刺激により右側の眼輪筋に $0.9 \mathrm{mV}$ ，口輪筋に $2.6 \mathrm{mV}$ で反応があったが左側は反応がほとんど見られ なかった。

(3) 画像検査

平成 9 年 7 月 24 日当科入院時の中耳 CT（図 3 ) では両 側の乳突洞内に貯留液を思わせる low density area を認 め鼓膜所見および耳漏の存在と併せて左側の乳突洞炎お よび右側の滲出性中耳炎と考えた.

（4）血液生化学検査

異常を認めなかった.

治療执よび経過: 平成 9 年 7 月 24 日当科入院し CT 所 見，細菌感染を伴った耳漏の分泌のあること等より化膿 性中耳炎に伴う左末梢性顔面神経麻痺と考えステロイド (サクシゾン $300 \mathrm{mg}$ )に併せて抗生剤の点滴静注を 7 日 間, ATP, メコバラミンの点滴静注を17日間施行した. 星状神経節ブロックも併用していたところ，8月18日に 突然, 右の顔面神経麻痺が発症した.

図 4 は右顔面神経麻痺発症時のものである．この写真 のように両側とも完全な閉眼は不能であった。また，口 笛を吹くような口輪筋の動き，額の䀛寄せは全く不能で 顔面スコアは 0 の状態であった。

右側の顔面神経麻痺が出現したため再びステロイドを はじめ同様の薬剤と両側の星状神経節ブロックによる治 療を行ったが，顔面神経麻痺は不変で長期にわたる抗生 剂投与にもかかわらず漿液性の分泌物が続くため鼓室乳 突洞の清掃と併せて 8 月 20 日に左顔面神経減荷術を施行 した。

右

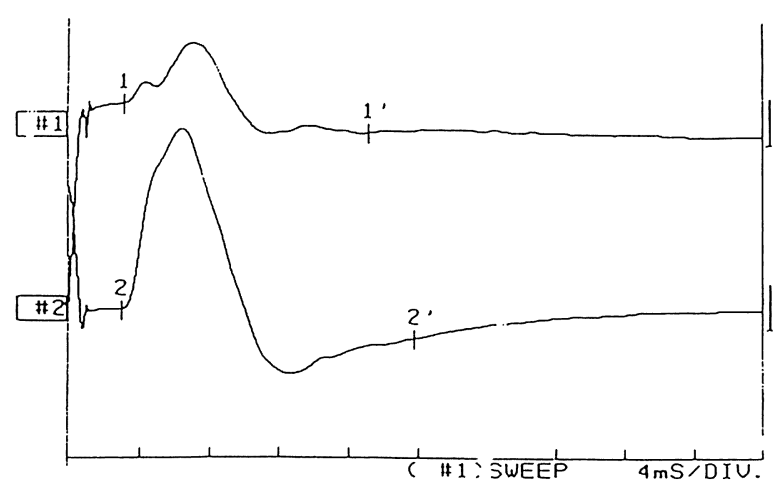

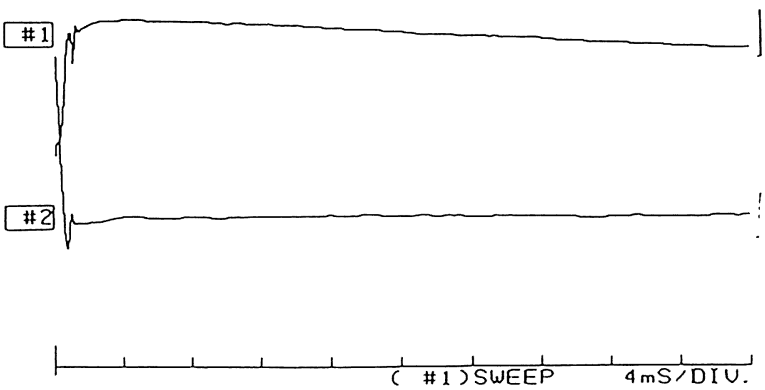

図 2 顔面麻痺発症 42 日目の筋電図 


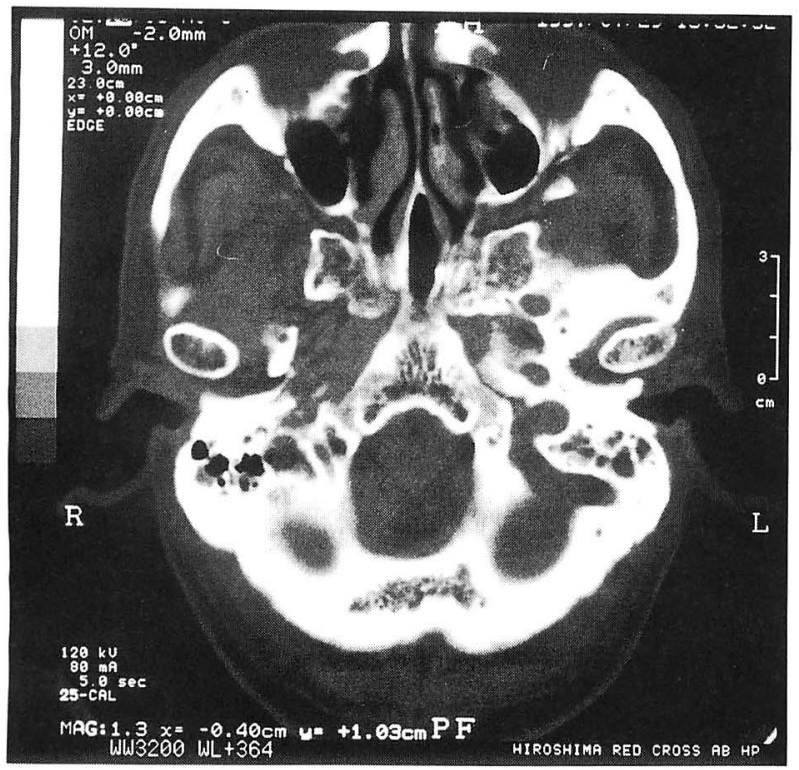

図 3 中耳 CT

両側の乳突洞内に貯留液を思わせる low density area を 認める。

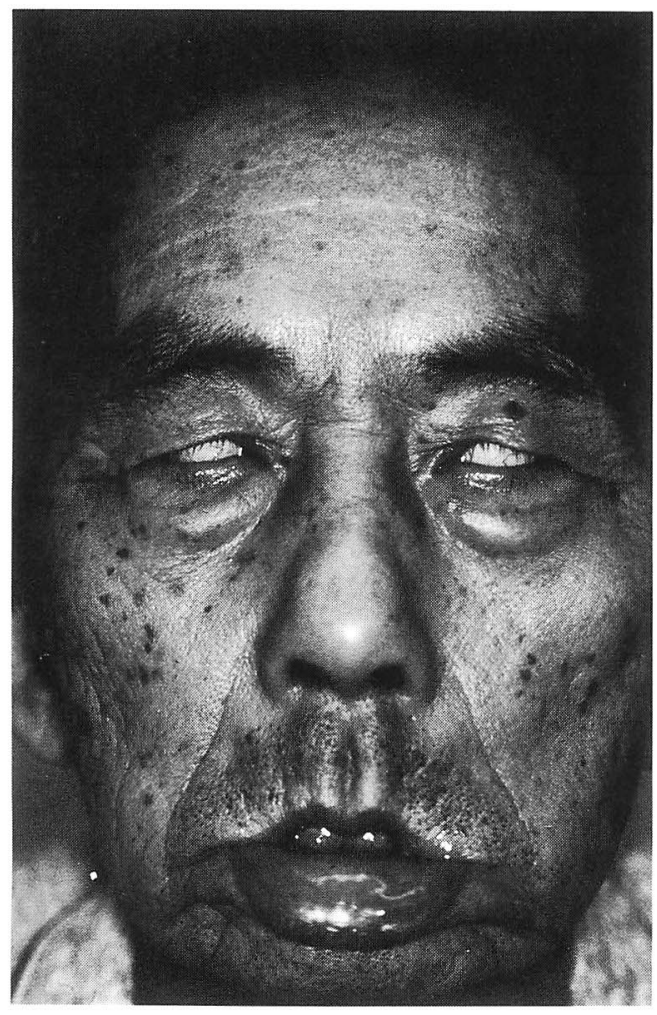

図 4 右顔面神経麻痺発症時
手術所見：左乳突洞内は炎症性の肉芽で充満して扣り 強い炎症後の变化が見られた。顔面神経管は全長にわた り骨欠損はなかった．手術により露出させた顔面神経鞘 は線維性に肥厚して抏り，この神経鞘を垂直部から水平 部にわたって切開すると顔面神経は水平部で浮腫状であ った。

手術を行った左側の麻痺は術後30日目より改善の兆し が現われ現在では70\%程度回復している. 右側も加療 13 日後より改善の兆しが現われたため減荷術は行わず，現 在では $60 \%$ 程度回復している.

\section{考察}

両側性顔面神経麻痺の頻度は，例光ば，杉山ら ${ }^{4)}$, 中 村ら5) の報告では，それぞれ顔面神経麻痺681例中12例 $(1.8 \%) ， 1856$ 例中42例(2.3\%)であった。

両側性顔面神経麻痺の分類は, 安田 $5^{6)}$, 柳原ら ${ }^{7)}$ に よると左右の顔面に麻㽻がほとんど同時に起こる場合と 左右の顔面麻痺が異なった時期に起こる場合とがある (表 1 ). 今回の症例は左側に麻痺が起こり46日後に右側 の麻痺が起こっているので時期の異なる場合にあたる.

両側性顔面神経麻㽻の原因(表 2 ) として，松本ら ${ }^{2)}$ は ベル麻瘏，外傷性，中耳炎性，Hunt 症候群，中枢神経 疾患, 多発性硬化症等多くの原因を挙げているが本症例 ではヘルペス瘆はなく，血液学的検査も異常を認めなか った。また，血清ウイルス学的検査ではへルペス IgG

表 1 両側性顔面神経麻痺の分類

左右の顔面麻痺の発症時期が医とんど同時である場合

$\bigcirc$ 左右の顔面麻痺の発症時期が異なる場合

(柳原ら ${ }^{7)}: 1980$ より引用)

表 2 両側顔面麻痺の原因

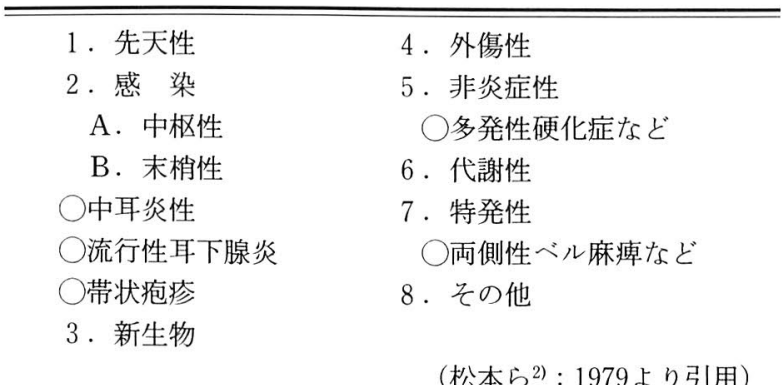


抗体は80倍であったが, ヘルペス IgM 抗体陰性であっ たことから最近のへルペス感染は否定された.さらに， 他の神経症状を認めず頭部 MRIでも異常を認めなかっ た. 両側同時性顔面神経麻瘏の髄液検査で蛋白細胞解離 を示す例では Guillain-Barre 症候群 (GBS) を疑う報告 もある. 例光ば, 川井田ら ${ }^{8)}$ は, 両側同時性顔面神経麻 痺では予後良好なこと，上気道感染が先行すること，一 側性顔面神経麻㾝の䯣液検查ではみられない䯣液での蛋 白細胞解離を認めたことに注目し, 両側同時性顔面神経 麻痺を GBS の純脳神経型と考えている. 今回の両側麻 痺の原因については䯣液検査では異常を認めず両側非同 時性顔面神経麻㾝であることより GBS は考えにくく， 左耳より多量の耳漏が認められたこと，および手術所見 から左側については中耳炎性と考兄, 右側の麻痺につい ては疑問はあるがべル麻痺といったように異なった原因 による両側顔面神経麻痺と考えた。

中耳炎性顔面神経麻痶の治療については松本ら 2) は保 存的治療が優先するが, 回復の兆しがない時は, 積極的 飞乳突洞削開術括よび顔面神経減荷術を行うことを方針 としている. 今回の症例のように左側顔面神経減荷術を 施行した後 $70 \%$ 程度回復していることを考えると治療の 選択は重要で，回復の兆しがない場合，脱簿所見のある 時は, 時をらつさぬ乳突洞削開術捛よび顔面神経減荷術 が肝要である.

$$
\text { まとめ }
$$

74歳男性の両側性顔面神経麻痷を経験した. 最初は左
側に麻痺を生じ46日後に右側に顔面神経麻痺を生じた。 本症例は左側は中耳炎性麻痺によるものと考兄られ右側 については疑問はあるがベル麻疩といったように左右異 なった原因によるまれな両側性顔面神経麻痺と考えた。

\section{参考文献}

1）森 充広, 平松 隆, 海田健宏: 両側同時性顔面神経麻瘏 例. 耳鼻臨床 $88: 1263 \sim 1268,1995$.

2 ）松本 康, 柳原尚明, 丘村 熙: 急性中耳炎に上る両側同 時性顔面神経麻瘦の 2 症例. 耳鼻 $25: 805 \sim 810,1979$ 。

3) Weintraub M : Facial Diplegia. Arch Otolaryng $102: 311$ $\sim 312,1976$.

4）杉山茂夫, 玉置弘光, 中島礼士 : 家族性の反復性顔面神経 麻痺症例. 日耳鼻 $76: 829 \sim 832,1973$.

5 ）中村光士郎, 松本 康, 柳原尚明：両側性拉よび反復性顔 面神経麻㿎の統計的観察 一その 1 原因について一. 耳鼻 臨床 $73: 1673 \sim 1678,1980$.

6) 安田宏一, 池田雄祐, 光安如成: 両側同時ベル麻疩の一例. 耳鼻 $24: 370 \sim 375,1978$.

7 ）柳原尚明, 西村宏子, 陌間啓芳: 顔面神経麻痺程度の判定 基準に関する研究. 日耳鼾 $80 ： 799 \sim 805,1977$.

8 ) 川井田政弘, 神埼 七, 岡本亮二, 他: 末梢顔面神経麻疸 の背景因子の検討一ウイルス，耐糖能，サルコイドーシ ス, 䯣液異常等との関連について一. Facial N Res Jpn 5 ： 127 134, 1985.

$$
\left(\begin{array}{l}
\text { 別刷請求先 : 森 良樹 } \\
\text { †730-0052 広島市中区千田町1-9-6 } \\
\text { 広島赤十字・原爆病院耳鼻咽喉科 }
\end{array}\right)
$$

